\title{
IS THE BOULDER BATHOLITH A LACCOLITH?
}

\author{
DISCUSSION $^{1}$ OF PAPER BY A. C. LAWSON.
}

Sir: Professor A. C. Lawson has recently published a paper entitled "Is the Boulder Batholith a Laccolith? A Problem in Ore Genesis," ${ }^{2}$ which is of much interest to economic geologists for several reasons: and this interest is heightened by the fact that Professor Lawson is one of few vigorous opponents of the theory of the magmatic derivation of ore deposits. In this publication he challenges the current interpretation that the great granite intrusion in southwestern Montana, known as the "Boulder Batholith," is a batholithic mass. He reaches the conclusion that it is in reality an irregular transgressive laccolith. From this conclusion he believes that certain consequences important to the theories of ore genesis follow as necessary deductions. Of these, the most important is that the metalliferous lodes causally related to the intrusion of the Boulder mass were deposited by ascending hot waters of meteoric origin. It is my purpose here to discuss some of these deductions.

The distinction between a laccolith and a batholith is first clearly defined by Professor Lawson. A laccolith is essentially an injected mass resting upon a bottom or underlying partition; a batholith, on the other hand, differs fundamentally from a laccolith in that it is not injected, and that whatever the nature of the bottom on which it rests, it has not come to place upon that bottom by moving over it, but by being developed above it. The Sudbury laccolithic sheet, the Duluth gabbro laccolith, and the Bushveld laccolith are cited to prove that mere size is no argument against the laccolithic nature of the Boulder mass. Certain structural evidence is then adduced, principally based upon brief and rather general statements by Sales and Barrell, at first glance somewhat conflicting in character, and upon interpretations of the geologic maps accompanying Professional Paper 74 and Bulletin 527 of the U. S. Geological Survey. From this evidence

${ }^{1}$ Published with the permission of the Director, U. S. Geological Survey.

2 Univ. Calif. Publ. Bull. Dept. Geol., Vol. 8, pp. I-15, I9I4. 
the conclusion is derived that "the deformation of the strata and the invasion of the granite were in a broad sense coincident manifestations of a general diastrophism, and that the synclinal structure of the rocks surrounding the Boulder mass is genetically connected with the development of the latter." Here I may cite some structural evidence from first hand observations. The prevailing rocks beneath which the Boulder mass was intruded consist of series of bedded andesitic and latitic lavas and breccias. On the north end of the batholith near Helena, the rocks, however, are prevailingly of sedimentary origin, ranging from Algonkian to Cretaceous. An east-west section from Elkhorn on the east margin of the Boulder intrusive to Thunderbolt Mountain on the west shows that the rocks on the east margin dip gently to the east and that on the west margin they dip gently to the west. The line of this section crosses a remnant of the roof still remaining within the central area of the intrusion, and in this patch the strata strike in diverse azimuths and dip up to $45^{\circ}$. The features indicated along the line of this section are that a certain amount of doming accompanied the intrusion and that portions of the roof, as I have elsewhere pointed out, have suffered partial collapse and foundering. ${ }^{1}$ At Helena the rocks dip in steeply toward the granite, but the contact is of a transgressive character. To the northwest, however, the prolongation of the intrusive coincides with a well-developed synclinal structure in the surrounding sedimentary rocks. The contact here. as elsewhere, is of a transgressive nature, but it is not improbable that at greater depth the sedimentary rocks pass beneath the granite and constitute a synclinal basement upon which it rests. Possibly, however, there may be a certain limited amount of laccolithic injection of the quartz monzonite along the periphery of the main batholithic mass. It may be conceded nevertheless that as a working hypothesis, the conception advanced by Professor Lawson is entitled to much weight, perhaps to as much weight as the batholithic hypothesis.

If, for the sake of argument, it be granted that the Boulder

1 U. S. Geol. Survey Bull. 527, p. I08, I9r3. 
intrusive mass is essentially an irregular transgressive laccolith, does Professor Lawson's conclusion necessarily follow that the genetically associated ore deposits were formed by waters of meteoric circulation? This brings up the fundamental question of the amount of original water and other volatile constituents which granite magmas contain at the time of their intrusion. In the 40's Scheerer estimated that a magma might carry up to 50 per cent. of water, but that it was probably nearer 5 to 20 per cent. Since his time this estimate has not been fixed with any greater quantitative precision. It seems probable, however, that different magmas have different original concentrations of volatile constituents-that this is as specific a property of an individual magma as is its chemical composition - but how to obtain an independent measure of the original gas-content, we have not yet been able to devise. If appeal is made to intensity of contact metamorphism or to abundance of ore deposits around an intrusive mass as proof of a large primary content of magmatic water and other volatile constitutents, the opponents of this idea will inevitably retort that this is but arguing in a vicious circle.

In describing the relationship between the Heemskirk massif and its ore deposits, L. Keith Ward, ${ }^{1}$ of the Tasmanian Geological Survey, comes to the conclusion that this granite intrusive, which according to usual interpretation would be termed a batholith, in reality possesses a very definite bottom above which were situated the magmatic foci, whence the ore-forming constituents were expelled. It is therefore an irregular transgressive laccolith, or to use Professor Daly's term, a "chonolith." The argument leading to this conclusion is based mainly upon the beliefs that the roots of the vein series appear to be, beyond all shadow of doubt, direct products of differentiation, and that the period of primary ore deposition, which was co-ordinate and coincident with the period of magmatic consolidation, appears to have terminated abruptly.

This is an interesting result: from the hypothesis that the

1 "The Heemskirk massif-Its Structure and Relationships," Australasian Assoc. Adv. Sci., Vol. 13, pp. 165-175, I912. 
Boulder intrusion is a laccolith, Professor Lawson deduces as a necessary conclusion that the ore deposits were deposited by waters of meteoric origin; from the hypothesis that the ore deposits of the Heemskirk intrusion are of magmatic derivation, Keith Ward deduces as a necessary conclusion that the Heemskirk intrusion is a laccolith. These conclusions, both of which emphasize how closely the problems of ore genesis are tied to our conceptions of the nature of the intrusive mass with which the ores are associated, indicate that neither one nor the other conclusion follows necessarily.

The presence of tourmaline in the Boulder ore deposits is regarded by Professor Lawson as a very strong argument in favor of magmatic emanations as a direct agency in ore deposition; but he says the argument lacks conclusiveness in the fact that the deposits under discussion are distinctly later than the intrusion of the aplites, which in turn are intruded in the quartz monzonite forming the main mass of the Boulder batholith. The charge of inconclusiveness here made applies specifically to the tourmaliniferous deposits of the Helena mining region; a fortiori, it must apply to the Butte deposits, inasmuch as they are not merely later than the aplite intrusions, but are also later than the granite porphyry dikes ("Modoc porphyry") cutting the quartz monzonite. The defense of the hypothesis that the Butte deposits are of magmatic derivation will be left to the geologists who have described those ore bodies, in the hope that Professor Lawson's vigorous challenge of their views will elicit a stronger presentation than they have yet attempted; and attention will now be directed to the genesis of the tourmaliniferous lead-silver deposits associated with the Boulder intrusion.

Now all that the presence of tourmaline in itself indicates is that the ore deposits containing it were formed at a high temperature. Yet, it is interesting to note, as indicating how strong traditional beliefs may become; that but one writer since the time of Sandberger, so far as I am aware, has ventured to consider tourmaliniferous deposits as formed by waters of meteoric deri- 
vation. J. B. Hill, during the course of the recent resurvey of the Cornish tin districts, published a paper in which he held that meteoric waters penetrated so near the region of diminishing igneous activity that solutions were effected at high temperature and deposited their constituents from the ascending currents. Stress was laid on the fact that the granite contains the necessary constituents for the lodes: tin and fluorine in the micas, and boron and fluorine in the pyrogenic tourmaline. But in the final publications on the tin districts of Cornwall, MacAlister ${ }^{2}$ maintains the conclusion that the deposits with their tourmaline are of pneumatolytic origin and are produced by direct primary contributions from the magma. The argument must, however, appear inconclusive to the opponents of the magmatic theory, for the tin lodes cut the granite porphyry dikes (elvans) which in turn cut the granite forming the main intrusive masses.

Realizing that the presence of tourmaline in ore deposits does not of itself necessarily prove the magmatic derivation of the oreforming solutions, I attempted, in sketching the genesis of the tourmalinic silver-lead deposits associated with the Boulder intrusion, to indicate the line of descent of the solutions and to show by what process of magmatic concentration they originated. ${ }^{3}$ The fact that the ore deposits are distinctly later than the intrusion of the aplite, instead of being an element of weakness in the chain of reasoning, appears to be distinctly an element of strength, for the evidence shows that the aplites represent a stage of magmatic differentiation intermediate between the quartz monzonite and the ore-forming solutions. The formation of the aplite magma, which took place by fractional crystallization, was manifestly accompanied by a magmatic concentration of tourmaline, and at certain localities the aplite is filled with tourmalinic nodules

I "The Plutonic and Other Intrusive Rocks of West Cornwall in their Relation to the Mineral Ores," Royal Geol. Soc. Cornwall, Vol. I2, pp. 5466I5, I901.

2 Hill, J. B., and MacAllister, D. A., "The Geology of Falmouth and Truro and of the Mining District of Camborne and Redruth," Geol. Survey England and Wales Memoir, pp. 167-171, 1906.

3 "Ore Deposits of the Helena Mining Region, Montana," U. S. Geol. Survey Bull. 527, pp. 5I-53, I9I3. 
of pyrogenic origin. The composition of these nodules, consisting as they do of silicon, aluminum, boron, iron, and potassium, is singularly like that indicated for the composition of the oreforming solutions as shown by the metasomatic alterations that they effected in the wall rocks of the ore deposits. The tourmaline-bearing nodules were regarded, therefore, as in essence globules of the differentiate from which the ore solutions were derived, and which had congealed within the magma at the centers at which they were collecting.

Essentially this same argument had been previously used by L. Keith Ward in a notable paper which has since come to my attention. ${ }^{1}$ In the Heemskirk-Comstock-Zeehan region, Tasmania, the magma that acted as ore bringer is in places characterized by the presence of enormous numbers of nodules composed of quartz and tourmaline with smaller quantities of feldspar and traces of cassiterite. Ward says:

"The tendency for silica, aqueous, boric, and other vapors to collect in the heart of the magma was checked in some portions of the mass for reasons thus far not fully determined, and a number of small, separate, and isolated segregations of quartz and tourmaline resulted. Thus the nodular tourmaline granite was formed."1

An even more impressive example of this same phenomenon has recently been described from Mt. Mulatto, at Predazzo in southern Tyrol. ${ }^{2}$ The ore deposits here are stringer lodes carrying tourmaline, quartz, apatite, scheelite, chalcopyrite, pyrite, and arsenopyrite. The granite, which is the ore bringer, contains tourmalinic nodules surrounded by pegmatitic aureoles of coarse quartz and feldspar. Some of the nodules carry apatite, scheelite, fluorite, sulphides (principally chalcopyrite), and calcite.

1 "An Investigation of the Relationship between the Ore Bodies of the Heemskirk-Comstock-Zeehan Region and the Associated Ignecus Rock," Australasian Assoc. Adv. Sci., Vol. 13, pp. 148-164, I912. This is one of a series of three papers; the publication by L. Keith Ward earlier cited is also one of this series.

2 Op. cit., p. 152.

3 Granigg, B., "Die turmalinführende Kuyferkies-Scheelitlagerstätte am Monte Mulatto bei Predazzo (Südtirol)," Zeitschr. prakt. Geol., 19r3, pp. 481-497. 
The nodules are clearly of pyrogenic origin and are locally arranged in the granite according to an irregular schlieren structure. The pegmatitic aureoles point to an unusually high concentration of the volatile fluxes of the magma, such as water and others, and the whole phenomenon leads inevitably to the conclusion that the nodules represent portions of the "acid extract" frozen in place. It is believed then that these examples from Montana, Tasmania, and especially that from Predazzo throw light upon the processes by which the ore-forming solutions were evolved within the cooling and consolidating magma: they afford as nearly direct a proof of the genetic affiliation of the ore deposits and the intrusive rock as can in the nature of things be reasonably expected.

AdOLPH KNOPF.

\section{THE OCCURRENCE OF ALUMINUM HYDRATES IN CLAYS.}

Sir: I have read with some interest M. G. Edwards' paper on The Occurrence of Aluminum Hydrates in Clays, in Economic Geology for March, I9I3.

I quite agree with the author that aluminum hydrate may be present in many clays in at least small amounts; in fact $I$ have held this view for some years. Moreover, the presence of one aluminum hydrate, gibbsite, has been demonstrated by one of my former graduate students, ${ }^{1}$ who showed that it undoubtedly existed in certain highly aluminous clays from Kentucky and probably several others described in the same paper.

The point I wish to emphasize here, however, is that it is unsafe to attempt an interpretation of the mineralogical composition of clay from its chemical analysis for the following reasons :

I. Many published chemical analyses are incomplete or insuffciently differentiated. Titanium, for example, is not always separated, being left with the alumina, and may be present in amounts up to 2 or more per cent.

2. Some clays contain considerable muscovite, which if present

1 S. L. Galpin, Trans. Amer. Ceram. Soc., XIV., p. 301, 1912. 